\title{
Knowledge Acquisition in Supply Chain Partnerships: The Role of Power
}

\author{
${\text { Qile } \mathrm{He}^{\mathrm{a}} \text {, Abby Ghobadian }}^{\mathrm{b}}{ }^{1}$, David Gallear ${ }^{\mathrm{c}}$ \\ ${ }^{a}$ University of Bedfordshire Business School, Luton, Bedfordshire, LU1 3JU, UK \\ ${ }^{\mathrm{b}}$ Henley Business School, University of Reading, Greenlands, Henley-on-Thames, \\ Oxfordshire, RG9 3AU, UK \\ ${ }^{\mathrm{c}}$ Brunel Business School, Kingston Lane, Uxbridge, Middlesex, UB8 3PH, UK
}

\begin{abstract}
Knowledge is recognised as an important source of competitive advantage and hence there has been increasing academic and practitioner interest in understanding and isolating the factors that contribute to effective knowledge transfer between supply chain actors. The literature identifies power as a salient contributor to the effective operation of a supply chain partnership. However, there is a paucity of empirical research examining how power among actors influences knowledge acquisition and in turn the performance of supply chain partners. The aim of this research is to address this gap by examining the relationship between power, knowledge acquisition and supply chain performance among the supply chain partners of a focal Chinese steel manufacturer. A structured survey was used to collect the necessary data. Two conceptually independent variables - 'availability of alternatives' and 'restraint in the use of power' - were used to assess actual and realised power respectively. Controlling for contingencies, we found that the flow of knowledge increased when supply chain actors had limited alternatives and when the more powerful actor exercised restraint in the use of power. Moreover, we found a positive relationship between knowledge acquisition and supply chain performance. This paper enriches the literature by empirically extending our understanding of how power affects knowledge acquisition and performance.
\end{abstract}

\section{Keywords:}

Supply chain partnership

Knowledge acquisition

Power

Supply chain performance

\footnotetext{
${ }^{1 *}$ Corresponding author: Abby Ghobadian, Henley Business School, University of Reading, Greenlands, Henley-on-Thames, Oxfordshire, RG9 3AU, UK. Email: abby.ghobadian@henley.reading.ac.uk Tel: +44 (0)1491 418756. Other authors: Qile.He@ beds.ac.uk; David.Gallear@brunel.ac.uk
} 


\section{Introduction}

This paper examines the relationship between power and knowledge transfer among supply chain partners because this is an important relationship and research in this area is scarce. Supply chain partnership is one of the most widely adopted forms of collaborative interfirm alliance (Pekar and Allio, 1994). This is largely due to features that afford flexibility within the relationship such as contractual agreements between partners (if one exists at all) that are unlikely to possess the rigidity and legal agreements of the contracts prevalent in other forms of interfirm relationship, for example joint ventures, $R \& D$ partnerships and cross licencing (e.g. Wilson, 1995; Frankel et al., 1996; Lambert et al., 1996).

A number of theories are used to explain the rationale for entering into collaborative agreements. These include transaction cost economics (TCE) (Williamson, 1975), the resource-based view (RBV) (Barney, 1991), resource dependence theory (RDT) (Pfeffer and Salancik, 1978), and the relational view (Dyer and Singh, 1998). According to TCE firms enter into collaborative agreements in order to reduce the cost of participating in the market. Here, collaborative agreements unlike merger and acquisition offer a restricted hierarchy because of partial absorption of interdependencies (Fitzroy et al., 2011). The RBV posits that firms enter into collaborative agreements to complement their resources (Murray et al., 2005). According to RDT organisations are constrained and affected by their environments and attempt to manage resources dependencies by pursuing from amongst five options one of which is interorganisational collaboration (Pfeffer and Salancik, 2003). As such, RDT posits that firms use collaborative arrangements to reduce uncertainty and interdependence (Harrigan and Newman, 1990). The relational view postulates that idiosyncratic interfirm linkages are a source of superior rent. Dyer and Singh (1998) identify four sources of relational rents: (a) relation-specific assets; (b) knowledge sharing routines; (c) complementary resources / capabilities; and (d) effective governance. The unit of analysis in the case of the relational view is networks and/or dyads of firms, while the firm is the unit of analysis in the case of the other three theories. There are two important points to note. First, RBV, the relational view, and RDT are complementary. For example, the RBV posits that inter-organisation collaboration facilitates the development of valuable resources, while the relational view argues that shared resources and routines are a source of competitive advantage. In essence RBV describes how/why, and the relational view describes what/why. Second, as we discuss later, RDT is the only theory that implicitly recognises the significance of power. 
The knowledge based view (KBV) uses the logic of RBV to posit that "knowledge" is a major determinant of competiveness (Kogut and Zander, 1992; Grant, 1996). Moreover, scholars postulate that knowledge sharing between alliance partners is a major contributor to enhanced competitiveness (Levinson and Asahi, 1995; Mowery et al., 1996; Inkpen, 1998). Not surprisingly, knowledge management practices among supply chain partners have attracted much attention (e.g. Beecham and Cordey-Hayes, 1998; Kotabe et al., 2003; Hult et al., 2004; Handfield and Lawson, 2007; Modi and Mabert, 2007; Rauniar et al., 2008; Pedroso and Nakano, 2009). The literature suggests that partnerships between buyer and supplier firms are a conduit for knowledge sharing that can result in improved performance along the entire supply chain (Heide and Miner, 1992; Dyer and Nobeoka, 2000; Krause et al., 2007; Rauniar et al., 2008; Lawson et al., 2009; Cao and Zhang, 2010).

One strand of empirical research on supply chain partnerships has focused on isolating and examining the impact of key attributes of partnership (most commonly trust, commitment, interdependence and shared meaning) on the exchange of knowledge between supply chain partners (e.g. Spekman et al., 2002; Hult et al., 2004; Dyer and Hatch, 2006; Krause et al., 2007; Modi and Mabert, 2007; Panayides and Venus Lun, 2009). According to the extant literature, power among supply chain partners is another key attribute influencing the operational behaviour and performance of supply chain partners (Lascelles and Dale, 1989; New, 1998; Cox, 1999; Cox et al., 2001; Hallikas et al., 2005; Ke et al., 2009; Liu et al., 2010). The relative power of partners is likely to significantly influence the distribution of responsibilities and the flow of benefits between them (Benton and Maloni, 2005; Hingley, 2005; Zhao et al., 2008; Ke et al., 2009; Esmaeili and Zeephongsekul, 2010).

The importance of power goes beyond academic curiosity. According to Cox (1999), cognisance of power is of significant importance to practitioners as well as academics. He argued that if they fail to understand power within the supply chain, both practitioners and academics 'may well be guilty of recommending strategies and operational practices that are inappropriate for the supply chains in which they operate' (Cox, 1999, p. 172). Maloni and Benton (2000) echoed this view and suggested that supply chain practice or research that does not account for the influence of power cannot be entirely realistic or implementable.

Research examining the relationship between power and different attributes of supply chain partnership is relatively sparse and generally suffers from methodological shortcomings. As far as we were able to ascertain, the majority of publications that do exist are either conceptual (e.g. Cox, 1999; Watson, 1999; Cox et al., 2001; Li et al., 2002; Cox, 2004; Sucky, 
2006; Crook and Combs, 2007; Muthusamy et al., 2008), or descriptive (e.g. Ogbonna and Wilkinson, 1998; Ireland, 1999; Watson, 2001). The lack of empirical research is potentially detrimental to the scholarly development of the field and to practice. Moreover, the limited number of empirical studies we were able to locate also displayed methodological limitations. The majority were case based, hence limiting the opportunity to develop generalisable conclusions (e.g. Bates and Slack, 1998; Sanderson, 2001; Cousins, 2002; Faria and Wensley, 2002; Hingley, 2005; Krajewski et al., 2005; Narasimhan et al., 2009). The few published studies using survey methodology lacked clarity on validity and reliability issues (e.g. Provan and Gassenheimer, 1994; Yeung et al., 2009). Furthermore, the previous quantitative studies we located that dealt with multiple dependent variables (e.g. Provan and Gassenheimer, 1994; Berthon et al., 2003; Caniels and Gelderman, 2007) generally used analytical methods such as multiple regression, rather than techniques such as canonical correlation, MANOVA, MANCOVA and SEM (structural equation modelling) as recommended by Podsakoff and Dalton (1987), which can simultaneously handle multiple dependent variables, and account for systematic variances of dependent variables and potential interrelationships between dependent variables. There are a small number of exceptions (e.g. Zhao et al., 2008; Ke et al., 2009). For example, Zhao et al. (2008) examined the impact of power and relationship commitment on supply chain integration using SEM. Ke et al. (2009) examined the impact of mediated and non-mediated power on electronic supply chain management system adoption, following a partial least squares technique. However, the foci of these two studies are significantly different from the focus of the present study.

Turning our attention to research specifically concerned with the relationship between power and knowledge sharing among supply chain partners, additional shortcomings are evident. First, despite its apparent importance (Beecham and Cordey-Hayes, 1998; Dyer and Nobeoka, 2000; Ke and Wei, 2007; Muthusamy et al., 2008; Ke et al., 2009) there is a dearth of empirical studies examining this relationship. It is a specific field of study that requires greater attention. Second, there is a divergence of views about the impact of power. Some authors argue that power is detrimental (Beecham and Cordey-Hayes, 1998; Maloni and Benton, 2000; Muthusamy et al., 2008), while others argue that power is helpful (Cox, 1999; Dyer and Nobeoka, 2000; Yeung et al., 2009). This lack of consistency, which we return to in the next section, provides a further impetus for this study.

Despite the existence of numerous literature contributions examining relationship factors such as trust, commitment, interdependence and shared meaning, the literature suggests that there 
is a lack of empirical research examining power in supply chain partnerships (see also Caniels and Gelderman, 2007), and especially its influence on interfirm knowledge transfer. Given that power tends to be a complex factor influencing the dynamics of supply chain partnership, we argue that it is critically important to give power due consideration in its own right through empirical study. For example, if we find that the restraint of power enhances knowledge acquisition, then management behaviour that seeks to take advantage of actual power purely for self-interest is likely in the long term to be detrimental to improving performance, and such behaviour needs to be re-evaluated. This paper therefore contributes to the extant literature by examining the relationship between power and knowledge transfer among supply chain partners. Furthermore, we extend the understanding by examining the effect on supply chain performance. If we find that knowledge acquisition enhances overall supply chain performance then boundary-spanning employees and managers should be empowered and equipped better to lead knowledge acquisition efforts, and supply chain partners should be encouraged to identify and develop the context-specific practices that will provide the necessary, sustainable communication and collaboration platforms. We use two constructs rooted in appropriate theory - 'availability of alternatives' and 'restraint in the use of power' - to assess power, and we also examine their interactional effect. We controlled for the effects of partnership duration in our model. As a further methodological extension, we controlled for contingencies present in previous studies that used a cross-section of independent firms, by focusing on actors operating within the supply chain of a single focal firm.

\section{Literature}

In this section we start by examining the concept of power and review how power might influence the behaviour of supply chain partners. This is followed by a discussion of the two indicators of power among supply chain partners. We then discuss knowledge acquisition which underpins any interfirm knowledge transfer process.

\subsection{Power and supply chain partnerships}

The study of power and its consequences has its roots in social and political sciences. More recently power has been used by scholars to study the behaviour of marketing channels and supply chain relationships (e.g. Ramsay, 1996; Maloni and Benton, 2000; Cox et al., 2001). Power is defined as the ability of one party (A) to get another party (B) to undertake an activity that B would not otherwise undertake (Cox et al., 2001). The literature distinguishes 
between 'possessed power' and 'realised power'. 'Realised power' is the outcome of exercising 'possessed power' to bring about intended changes in the behaviour of the counterpart. According to Muthusamy and White (2006) power is either balanced or unbalanced. Balanced power exists where partnership actors possess broadly similar levels of power in influencing each other's decisions, while unbalanced power exists when one or more actors are able to manipulate decisions of the other actors (Muthusamy and White, 2006).

RDT characterises the firm as an open system, dependent on contingencies in the external environment (Pfeffer and Salancik, 1978). The theory attempts to address two key questions. First, where power and dependence come from ? Second, how managers use organisation's power and manage their dependence ? It posits that managers can and do act to reduce environmental uncertainty and dependence (Hillman et al., 2009). Central to this action is the concept of power - control over vital resources (Ulrich and Barney, 1984). According to Pfeffer and Salancik (1978) firms engage in interorganisational relationships to minimise uncertainties and dependencies. According to RDT if firm A, supplying intermediate goods, supplies only one major customer (firm B), then firm A is dependent on firm B, but if A supplies many firms and amongst these is firm B, then the two firms are mutually dependent on one another. To ensure consistency with RDT, through the rest of this paper we use "mutual dependence" to signify "balanced power" and "dependence" to signify "asymmetric power". Furthermore, as will become clear, our measure of power is rooted in dependence.

A number of scholars argue that in practice, mutual dependence among supply chain actors is a rarity due to differences in size, business resources, availability of alternatives and reputation (Ramsay, 1996). Moreover, New (1998, p.18) argued that 'even amongst firms who wished to work collaboratively, there seemed little chance of abandoning the sanctions and mechanism of the market'. This suggests that irrespective of intentions, power considerations play a role in every type of supply chain. The existence of two archetypal buyer-supplier relationships - 'strong buyer-weak supplier' and 'weak buyer-strong supplier' was illustrated by Bates and Slack (1998). However, the relationship between exchange partners is dynamic and may shift between partners from one transaction to another (Pfeffer and Salancik, 1978).

The literature is divided on how dependence influences purchaser-supplier relationships with some scholars pointing to a positive and others to a negative consequence. In his conceptual paper, McDonald (1999) argued that dependence of one party on another in the case of buyers and suppliers is likely to result in unproductive partnerships. This is a view shared by industry commentators. For example, the Competition Commission concluded that 'the 
transfer of excessive risk and unexpected costs by grocery retailers to their suppliers through various supply chain practices, if unchecked, will have an adverse effect on investment and innovation in the supply chain, and ultimately on consumers' (Competition Commission, 2008, p. 6). A number of empirical studies also support this proposition (Heide and Miner, 1992; Beecham and Cordey-Hayes, 1998; Maloni and Benton, 2000). Maloni and Benton (2000) argued that dependence has the potential to upset the mutuality of relationships, and therefore acts as a barrier to win-win integration. That is, that in an unbalanced relationship the dependency may not be reciprocal, such that one partner has power over the other but not vice versa (Wilson, 1995). Under such circumstances, exploitation rather than cooperation might result (Heide and Miner, 1992).

Other scholars argue that dependency may result in favourable consequences. For example, Lascelles and Dale (1989) suggested that buyers' purchasing power often contributes to successful quality improvement of the supplier. Cox (1999) makes a similar point, highlighting that Toyota used its suppliers' dependency to force them to adopt innovations such as an assembly based, demand-pull and just-in-time (JIT) system. Yeung et al's (2009) study concluded that coercive power improves supplier integration in Chinese supply chains, with or without the presence of trust. He argued that the exercise of power can potentially assure congruence in goals and activities, particularly in the absence of a well specified cooperation agreement. Each of these studies supports the view dependency may result in beneficial effects.

In addition to the disagreement present in the literature, there is a paucity of empirical research specifically examining the influence of power on the transfer of knowledge between supply chain partners.

\subsection{Indicators of power}

Unlike other attributes of supply chain partnerships, power cannot be readily measured (New, 1998). This is because power is an amalgam of complex social, economic and even psychological factors. It is a subjective phenomenon predicated on one's belief or expectation of how another actor will create an impact on oneself (Cho and Chu, 1994). Cox (1999) notes that when examining the power relationship between purchasers and suppliers operating within the same supply chain, it is the relative rather than the absolute power that is of interest. In this research we were interested in ascertaining the impact of power among the supply chain actors of a focal firm on the transfer of knowledge between them, rather than measuring 
the absolute power of each actor, which presents significant challenges.

The literature identifies two main indicators of power among actors within a focal firm's supply chain - 'availability of alternatives' and 'restraint in the use of power' (e.g. Hardwick and Ford, 1986; Ganesan, 1994; Kim et al., 2004; Crook and Combs, 2007). Powerdependence theory posits that inequalities in dependence create power imbalances that can lead to conflict in social exchange (Emerson, 1962). Although both actors could be mutually dependent in an exchange, it does not mean that they are equally dependent on each other (Kim et al., 2004). The less dependent actor will maintain a power advantage, resulting in a power imbalance. According to both marketing channel theory (e.g. Ganesan, 1994) and bargaining theory (e.g. Yan and Gray, 1994), an important source of dependence is a lack of alternatives. This accords with Hardwick and Ford's (1986) proposition that dependence, at whatever level, represents a poor option since it derives from a lack of choice. Although a supply chain partnership is formed on the basis of vertical complementarities (Christopher, 1998), which result in a certain level of mutual dependence, the lack of alternatives for one party will still limit the extent of equal say in the partnership (Anderson and Weitz, 1989). Building on this point, Crook and Combs (2007) suggest that members of a collaborative supply chain who furnish important resources or resources where control is concentrated, enjoy superior bargaining power. That is to say, a lack of alternatives increases dependency and reduces opportunity for independent behaviour. Conversely, a supply chain actor with alternatives is more likely to exploit those actors with fewer options (Anderson and Narus, 1990; Ganesan, 1994).

The second factor explaining power, 'restraint in the use of power', affects 'realised' power. It is highly probable that in a supply chain one party may be dependent on another due to differences in availability of alternatives (Ramsay, 1996; New, 1998; Cox, 1999). However, dependency may be neutralised if those with power exercise restraint in its exploitive use (Muthusamy and White, 2006). Consideration of long-term interests and future gains may encourage firms to adopt a policy predicated on the restricted use of power (Heide and Miner, 1992; Muthusamy and White, 2005), or power may, in fact, be used to positively influence a less powerful actor (Dyer and Nobeoka, 2000). Maloni and Benton's (2000) study showed that some automobile manufacturers with objective power chose to follow a cooperative approach, encouraging communication and sharing of benefits; while others opted for a competitive approach, exercising their leverage over weaker supply chain partners. In particular, however, Maloni and Benton (2000) observed that if a boundary-spanning manager 
is willing to restrain the excessive use of power over their partner and at the same time allow the partner to have a say, then each partner is more likely to have positive feelings or psychological attachment to the relationship due to a better balance in realised power.

The preceding arguments illustrate that availability of alternatives determines dependency among supply chain partners, while policy towards the deployment of power determines the realised power, and that together, these two variables determine the level of dependency among supply chain actors of a focal firm.

\subsection{Knowledge acquisition}

Knowledge acquisition is the process of accessing and absorbing knowledge through direct or indirect contact or interaction with knowledge sources (e.g. Inkpen and Dinur, 1998; Albino et al., 1999; Hult et al., 2004). KBV posits that the relative ability to acquire and develop knowledge is the key reason for variances in organisational performance (Grant, 1996). Accordingly knowledge acquisition capability is an essential contributor to the enhanced operation of supply chain partners. Typical knowledge acquisition mechanisms in supply chains include joint problem solving, ongoing manual adjustment (Love and Gunasekaran, 1999; Kotabe et al., 2003), supplier co-design (Beecham and Cordey-Hayes, 1998; Handfield et al., 1999) and co-location (Cousins et al., 2008). In the next section we discuss the influence of power on knowledge acquisition.

\section{Research hypotheses}

In this section we develop our hypotheses. In this research we deploy two conceptually distinct constructs to assess power: actual power and realised power. Figure 1 illustrates the hypothesised relationships between the study variables, namely availability of alternatives, restraint in the use of power, knowledge acquisition and supply chain performance, as well as between our two predictor variables. 


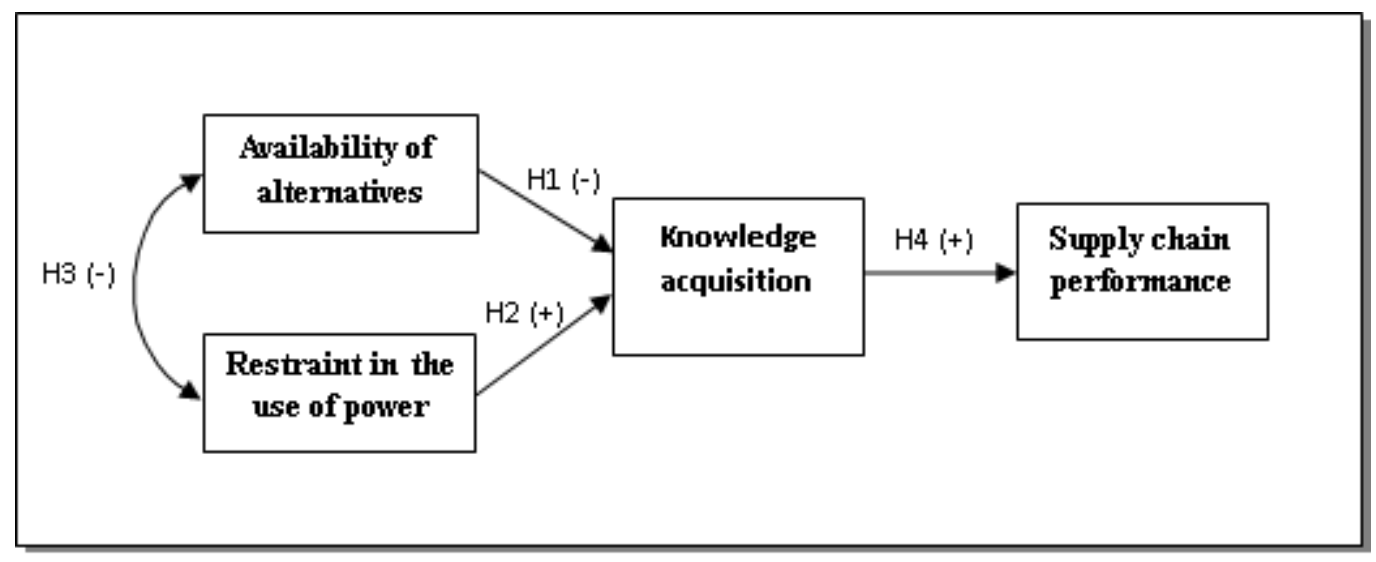

Figure 1. Framework of relationships between the indicators of power, knowledge acquisition and supply chain performance.

\subsection{The influence of power on knowledge acquisition}

The measure of actual power in this study is the availability of alternative partners, that is to say, the greater the number of potential alternatives the firm has, the less dependent the firm is and hence the more powerful it is. The extant literature suggests that actors with many alternative partners in a supply chain are less likely to become dependent on a partnership, and that these stronger actors might be tempted to exploit their power (Caniels and Gelderman, 2007). Moreover, a partner with many alternatives is more likely to restrict the out-flow of knowledge to protect its core proprietary assets or market position, although at the same time it is acknowledged that it may be more able to coerce knowledge out of the dependent partners (Albino et al., 1999). It has been noted, nevertheless, that stronger partners' lack of recognition for weaker partners can result in missed opportunities because valuable knowledge possessed by the weaker party is ignored (Beecham and Cordey-Hayes, 1998). Others argue that weaker partners with fewer alternatives are also likely to limit exposing valuable knowledge to stronger partners to avoid exploitation and to reduce the likelihood of obsolescence (Anderson and Weitz, 1989; Provan and Skinner, 1989). Anderson and Weitz (1989) note that there is ample evidence that the weaker party becomes mistrustful and apprehensive about the stronger party's intentions. The weaker partner consequently may even engage in a pre-emptive strike against the more powerful partner to protect its knowledge assets (Kumar et al., 1995). The evidence suggests that availability of alternatives is likely to discourage actors operating within a focal supply chain from being open with each other and sharing knowledge, as fear of exploitation and obsolescence are likely to be higher. Therefore, 
Hypothesis 1: The availability of alternatives to partners is negatively related to the level of knowledge acquisition between a firm and its supply chain partners.

The measure of realised power in this study is the voluntary restraint in the use of power or its constructive deployment. As discussed in section 2, firms' policies towards the use of power and the manner in which power is used has been shown to influence communication and information sharing (Maloni and Benton, 2000). Moreover, the evidence suggests that different levels of intention to exercise power may contribute to different levels of knowledge sharing and partnering from 'uninvolved' to 'integrated' (Beecham and Cordey-Hayes, 1998). For example, technology partnering involves extensive exchange of knowledge. This line of reasoning has a direct resonance for our study. Commitment to a relationship is enhanced when partners in less powerful positions observe and experience the willingness of a more powerful partner not to exercise that power for self-interest, but rather to restrain excessive use of that power in the interests of long-term gains (Muthusamy and White, 2005). The positive impressions generate positive reactions, opening up communication channels and engendering genuine desires to work more closely for mutual benefit. This enhanced communication and cooperation provides the platform for knowledge exchange. The arguments proffered suggest that restraint in the use of power will enhance knowledge sharing between supply chain partners. Therefore,

Hypothesis 2: The restraint in the use of power in a relationship is positively related to the level of knowledge acquisition between a firm and its supply chain partners.

\subsection{The relationship between the two indicators of power}

The indicators of power in this study are availability of alternatives and restraint in the use of power. Their relationship needs to be examined. The literature indicates that the two indicators of power are associated. Both resource-dependence theory (Pfeffer and Salancik, 1978) and power-dependence theory (Emerson, 1962) suggests that power can be viewed in terms of dependency. Dependence will increase when fewer alternative sources of exchange are available to the focal firm, or when replacing or substituting a current exchange partner is difficult (Heide and John, 1988). Waheed and Gaur (2012) built on the power-dependence theory and posited that the dependence of one party on a source is directly related to the rewards obtained from that source and inversely related to the number of alternative sources of those rewards. Thus the availability of alternatives to one party in a relationship reduces its dependency and often contributes to its power over the other (Anderson and Weitz, 1989). 
Especially in circumstances where one party possesses substantial leverage over the other, the stronger party will often exploit the dependence of its partner and create terms of trade in favour of itself (Heide and John, 1988; Anderson and Weitz, 1989). In the absence of moral or altruistic reasons, policy/belief, or the absence of tight contractual agreements as is particularly the case with supply chain partnerships, there is little incentive for a stronger partner with many alternatives to exercise restraint in the use of that power. In such circumstances, it is more likely to use that power in order to strengthen its competitive position (Ganesan, 1994). These arguments imply that restraint in the use of power is less likely to exist in situations when there is an availability of alternatives. Similarly, resource dependency theory (Caniels and Gelderman, 2007) supports the proposition that in circumstances where restraint in the use of power is observed to be exercised, it is likely to be a situation where there are less alternatives available, in other words, a situation where there is reason for restraint to be exercised (Muthusamy and White, 2006). These two situations equate to an inverse (or negative) correlation between the two indicators of power. Therefore,

Hypothesis 3: The availability of alternatives to actors in a supply chain partnership is negatively correlated with restraint in the use of power by more powerful actors.

\subsection{Knowledge acquisition and performance improvement}

The suggestion that acquisition of external knowledge enhances the performance of firms operating within a supply chain enjoys broad support (Wu and Hsu, 2001; Kotabe et al., 2003; Modi and Mabert, 2007; Rauniar et al., 2008; Yeung et al., 2008; Lawson et al., 2009). According to Dyer and Nobeoka (2000) and Ethiraj et al. (2005) the process of knowledge acquisition has a positive impact on a firm's capability. They noted that the process generates 'dynamic learning capabilities' and 'client-specific capabilities' respectively. Similarly, the quantity and variety of knowledge acquired by a firm has been found to enhance its innovativeness, eventually improving its performance (Wu and Hsu, 2001). Kotabe et al.'s (2003) study showed that sharing of technical know-how improved suppliers' performance. Similarly, it has been shown that undertaking knowledge transfer activities helps a firm create value for itself in the form of improved supplier performance (Modi and Mabert, 2007). Key attributes of customer knowledge that when shared have a significant impact on operational performance of the focal firm have also been identified (Yeung et al., 2008). Thus the thrust in the literature suggests that knowledge acquisition has a positive impact on performance. Therefore, 
Hypothesis 4: The level of knowledge acquisition from its supply chain partners is positively related to the supply chain performance of a focal firm.

\section{Research method}

To test the hypotheses, our research design was informed by Hult et al. (2002) and Hallikas et al. (2005). We used the supply chain of a single focal firm as our sampling frame. Examining the supply chain of a single focal firm is inherently fine grained because it avoids the confounding effects of studying a collection of firms operating within different supply chains (Hult et al., 2004). This is because management practices, power and sectoral contingencies vary from supply chain to supply chain. Therefore, our primary data were collected from the supply network of a large Chinese steel producer using a structured survey instrument.

The choice of industry is also important and the steel industry offers a number of advantages. First, the steel industry's supply chain represents a traditional chain with discernible explicit movements of raw materials and products, as well as flow of funds and information. Second, it is possible to accurately and readily locate upstream and downstream supplier firms, and hence develop a sample where both are well represented.

Finally, this approach is likely to yield a much higher response rate compared with the cold calling approach. Once the participation of the focal firm is secured, the assistance or sponsorship from the focal firm to secure access to other firms within its network may legitimise the survey and encourage greater response.

\subsection{Instrument design and administration}

We followed Dillman's (2000) tailored design method for developing and administrating our questionnaire in order to (a) ensure a close fit between the constructs, research context and the target population; and (b) maximise the response rate. To enhance validity and reliability, we adopted predictor variables from previous studies, provided that they were suitable for our target sample and congruent with our aims. To identify the appropriate measures of availability of alternatives and restraint in the use of power, we compared the relevant items from Anderson and Weitz (1992), Heide and Miner (1992), Ganesan (1994), Maloni and Benton (2000) and Muthusamy and White (2006). The items for availability of alternatives from (Ganesan, 1994) and the items for restraint in the use of power from (Heide and Miner, 1992) were found to be the most suitable. These items have been widely acknowledged and adopted by previous researchers as measures of power in inter-organisational research (e.g. 
Kemp and Ghauri, 2001; Storer et al., 2005; Waheed and Gaur, 2012). Similarly, we compared the measures of knowledge acquisition from Kotabe et al. (2003), Hult et al. (2004) and Ramasamy et al. (2006), and found Hult et al's (2004) items to be the most appropriate. Table 1 presents the items adopted. The predictor variables (availability of alternatives, restraint in the use of power, and knowledge acquisition) were measured using a 7-point Likert-type scale, where $1=$ strongly disagree and $7=$ strongly agree.

Table 1. Measures of predictor variables.

\begin{tabular}{|c|c|c|}
\hline Item label & Original measures & Adopted measures \\
\hline \multicolumn{3}{|c|}{ Availability of alternatives: original measures adapted from (Ganesan, 1994) } \\
\hline ALTRN1 & $\begin{array}{l}\text { If our relationship were discontinued with this } \\
\text { resource, we would have difficulty in making up the } \\
\text { sales volume in our trading area }\end{array}$ & $\begin{array}{l}\text { If our relationship were discontinued with this } \\
\text { partner, we would have difficulty in making up the } \\
\text { sales volume in our trading area }\end{array}$ \\
\hline ALTRN2 & This resource is crucial to our future performance & This partner is crucial to our future performance \\
\hline ALTRN3 & It would be difficult for us to replace this resource & It would be difficult for us to replace this partner \\
\hline ALTRN4 & We are dependent on this resource & We are dependent on this partner \\
\hline ALTRN5 & We do not have a good alternative to this resource & We do not have a good alternative to this partner \\
\hline ALTRN6 & This resource is important to our business & This partner is important to our business \\
\hline \multicolumn{3}{|c|}{ Restraint in the use of power: original measures adapted from (Heide and Miner, 1992) } \\
\hline RSTPW1 & $\begin{array}{l}\text { The parties feel it is important not to use any } \\
\text { proprietary information to the other party's } \\
\text { advantage [sic] }\end{array}$ & $\begin{array}{l}\text { Both parties feel it is important not to use any } \\
\text { proprietary information to the other party's } \\
\text { disadvantage }\end{array}$ \\
\hline RSTPW2 & $\begin{array}{l}\text { A characteristic of the relationship is that neither } \\
\text { party is expected to make demands that might be } \\
\text { damaging to the other }\end{array}$ & $\begin{array}{l}\text { A characteristic of the relationship is that neither } \\
\text { party is expected to make demands that might be } \\
\text { damaging to the other }\end{array}$ \\
\hline RSTPW3 & $\begin{array}{l}\text { The parties expect the more powerful party to } \\
\text { restrain the use of his power in attempting to get his } \\
\text { way }\end{array}$ & $\begin{array}{l}\text { Both parties expect the more powerful party to } \\
\text { restrain the use of its power in attempting to get its } \\
\text { way }\end{array}$ \\
\hline \multicolumn{3}{|c|}{ Knowledge acquisition: original measures adapted from (Hult et al., 2004) } \\
\hline KNACQ1 & $\begin{array}{l}\text { We meet regularly to find out what products we } \\
\text { need in the future }\end{array}$ & $\begin{array}{l}\text { Our firm and this partner meet regularly to find out } \\
\text { what products we need in the future }\end{array}$ \\
\hline KNACQ2 & $\begin{array}{l}\text { We do a lot of in-house research on products we } \\
\text { may need }\end{array}$ & $\begin{array}{l}\text { Our firm and the partner do a lot of in-house } \\
\text { research on products we may need }\end{array}$ \\
\hline KNACQ3 & $\begin{array}{l}\text { We poll participants once a year to assess the } \\
\text { quality of our supply chain services }\end{array}$ & $\begin{array}{l}\text { Our firm and this partner poll participants regularly } \\
\text { to assess the quality of our supply chain services }\end{array}$ \\
\hline KNACQ4 & $\begin{array}{l}\text { We periodically review the likely effect of changes } \\
\text { in the supply chain environment }\end{array}$ & $\begin{array}{l}\text { Our firm and this partner periodically review the } \\
\text { likely effect of changes in the supply chain } \\
\text { environment }\end{array}$ \\
\hline KNACQ5 & $\begin{array}{l}\text { Formal routines exist to uncover faulty assumptions } \\
\text { about the supply chain }\end{array}$ & $\begin{array}{l}\text { Formal routines between our firm and this supply } \\
\text { chain partner exist to uncover faulty assumptions } \\
\text { about the supply chain }\end{array}$ \\
\hline
\end{tabular}

For supply chain performance we adopted the framework proposed by Gunasekaran et al. (2001) because of its comprehensiveness. The literature examining specific facets of supply 
chain performance affected by knowledge transfer is underdeveloped, and hence we did not have a strong justification for including or excluding any of the 35 measures proposed by Gunasekaran et al. (2001) a priori. On the other hand, from a practical point of view we needed to include only measures of performance relevant to the supply chain under consideration. To this end we conducted four in-depth interviews with the appropriate senior managers of the focal firm and two field experts and consequently we eliminated 21 of the measures because of their poor fit with the needs of the focal firm and its supply chain partners, and retained 14 measures deemed most relevant (see Table 2).

Table 2. Measures of supply chain performance.

\begin{tabular}{ll}
\hline \multicolumn{1}{c}{ Areas of operation } & \multicolumn{1}{c}{ Performance measures } \\
\hline Plan (3 items) & Total cycle time \\
& Order lead time \\
& Information carrying cost \\
Source (2 items) & Achievement of defect free delivery \\
& Purchase order cycle time \\
Production (3 items) & Production cycle time \\
& Extent of quality cooperation \\
& Capacity utilisation \\
Delivery (3 items) & Delivery lead time \\
& Delivery reliability \\
& Responsiveness to urgent delivery \\
Customer service (3 items) & Customer query time \\
& Flexibility to meet particular needs \\
& Overall customer service \\
\hline Note: 14 items of supply chain performance adapted from (Gunasekaran et al., 2001). \\
\hline
\end{tabular}

Following the approach of previous researchers (Murray et al., 1995; Wu and Cavusgil, 2006), a relative-term scale was used. Respondents were asked to rate their performance relative to their major competitors for each performance indicator along a 7-point Likert-type scale, where 1 = far below, 7 = far above. Each performance indicator represents a single aspect of supply chain performance but arguably together they provide a holistic picture of firms' process related performance. Moreover, as suggested by Murray et al. (1995), under the assumption of linearity, summated measure cancels out the random error of individual items, and better reflects the underlying construct. Therefore, the performance indicators were summed together into a single response variable (labelled SCPERFRM) to measure the overall supply chain performance of the responding firms.

To assure face and content validity, ten pilot interviews were conducted with expert academics and practising managers in the UK and China. The aim was to ascertain relevance, 
significance, comprehensiveness and clarity. Since the final questionnaire was in Chinese, a translation-back-translation process was undertaken to ensure consistency in meanings (Maxwell, 1996; Kim and Lim, 1999).

In preparing for the fieldwork, it became apparent that not all of the suppliers and purchasers could be considered as partners. As such it proved difficult to construct a consistent and stable sampling frame preventing the use of traditional probability sampling (Robson, 1993). Instead, the snowball sampling procedure was used to identify the steel producer's supply chain partners. This is considered to be more effective when there is difficulty in identifying a stable sampling frame (Robson, 2002). Subsidiaries of the focal firm and its first-tier upstream and downstream supply chain partners were identified. Contacts from the first-tier partners were used to identify second-tier partners. Screening questions helped to identify the location (i.e. upstream or downstream of the firms) of respondents in the supply network of the focal firm, and to confirm the status as a partner.

The key informant method (Phillips, 1981) was used to select a top manager in each company with deep knowledge of supply chain operations. Respondents were asked to answer the questionnaire on the basis of the supply chain partnership with the focal firm or, in the case of second-tier supply chain firms, in relation to the most important or strategic partner they were supplying to or purchasing from within the focal firm's supply network. This approach ensured that the partnerships reported on were those most likely to impact on the supply chain performance of the responding firm (cf. Cousins et al., 2008).

\section{Results}

\subsection{Characteristics of the respondents}

We received 206 usable questionnaires from the focal firm, its subsidiaries, and upstream and downstream partners. 115 or slightly more than half of the responses represented downstream partnerships (55.8\%). The majority of the responses $(72.3 \%)$ or 149 responses represented first-tier (direct) partnerships. Overall, 54 responses are from the focal firm, remaining responses are either from the direct partners (95 or 46.1\%) or from the indirect partners (57 or $27.7 \%)$.

Top, senior and operations managers represented the majority (70.9\%) of the respondents (Table 3). The majority of these respondents were responsible for supply chain related operations such as procurement, production, distribution and customer services. In our case 
the great majority of respondents possessed first-hand knowledge of the supply chain practices, thus increasing confidence in the outcome of the study (Joshi and Sharma, 2004).

Table 3. Position of respondents.

\begin{tabular}{|c|c|c|}
\hline Position & Frequency & $\%$ \\
\hline Senior manager & 77 & 37.4 \\
\hline First line manager & 49 & 23.8 \\
\hline Operations manager & 43 & 20.9 \\
\hline $\mathrm{CEO} /$ chairman/managing director & 26 & 12.6 \\
\hline Administrative manager & 11 & 5.3 \\
\hline Total & 206 & 100.0 \\
\hline
\end{tabular}

The responding firms' sizes ranged from small to large (Table 4). The sample represented a wide range of businesses; however, the majority were consumers or suppliers of steel-related products (Table 4).

Table 4. Size and nature of business of responding firms.

\begin{tabular}{|c|c|c|}
\hline Number of employees & Frequency & $\%$ \\
\hline Less than 50 employees & 41 & 19.9 \\
\hline 50 to 99 employees & 27 & 13.1 \\
\hline 100 to 199 employees & 28 & 13.6 \\
\hline 200 to 499 employees & 31 & 15.0 \\
\hline More than 500 employees & 79 & 38.3 \\
\hline Total & 206 & 100.0 \\
\hline Sector & Frequency & $\%$ \\
\hline Steel processing and associated product & 24 & 11.7 \\
\hline Machinery \& equipment & 20 & 9.7 \\
\hline Round steel & 22 & 10.7 \\
\hline Rare-earth associated product & 13 & 6.3 \\
\hline Marketing \& distribution & 11 & 5.3 \\
\hline Steel production general & 11 & 5.3 \\
\hline Automobile \& motor & 9 & 4.4 \\
\hline Industrial chemical & 8 & 3.9 \\
\hline Iron mining and extraction & 8 & 3.9 \\
\hline Accessory \& component & 7 & 3.4 \\
\hline Seamless steel tube & 7 & 3.4 \\
\hline Railway lorry \& motor & 6 & 2.9 \\
\hline Recycling & 6 & 2.9 \\
\hline Steel plate & 6 & 2.9 \\
\hline New material & 6 & 2.9 \\
\hline Others & 42 & 20.4 \\
\hline Total & 206 & 100.0 \\
\hline
\end{tabular}




\subsection{Validity and reliability analysis}

Although all of the scales used in this study were validated by previous studies, their adoption did not preclude the need to further assess validity and reliability. Following the suggestions of Hair et al. (1998), both exploratory factor analysis (EFA) and confirmatory factor analysis (CFA) were used to examine the reliability and validity of the survey instrument. Supply chain performance was represented by a single observed variable (SCPERFRM) and hence was not subjected to EFA and CFA.

Exploratory factor analysis was carried out with the original scales: availability of alternatives (ALTRN), restraint in the use of power (RSTPW) and knowledge acquisition (KNACQ). As there were no theoretical reasons to assume that underlying factors should be uncorrelated, oblique rotation was employed (Hair et al., 1998). The rotated factor matrix (Table 5) shows that all the items have relative higher loadings on their corresponding factors, thus indicating that the three predictor variables can be explained by three separate underlying factors.

Table 5. Rotated factor matrix of original measures.

\begin{tabular}{|c|c|c|c|}
\hline & \multicolumn{3}{|c|}{ Factor } \\
\hline & 1 & 2 & 3 \\
\hline ALTRN1 & 0.722 & & \\
\hline ALTRN2 & 0.807 & & \\
\hline ALTRN3 & 0.845 & & \\
\hline ALTRN4 & 0.924 & & \\
\hline ALTRN5 & 0.911 & & \\
\hline ALTRN6 & 0.812 & & \\
\hline RSTPW1 & & & 0.638 \\
\hline RSTPW2 & & & 0.859 \\
\hline RSTPW3 & & & 0.601 \\
\hline KNACQ1 & & 0.706 & \\
\hline KNACQ2 & & 0.752 & \\
\hline KNACQ3 & & 0.887 & \\
\hline KNACQ4 & & 0.759 & \\
\hline KNACQ5 & & 0.789 & \\
\hline Factor with eigenvalues $>1$ & 6.616 & 2.347 & 1.375 \\
\hline$\%$ of variance explained & 47.260 & 16.762 & 9.824 \\
\hline \multicolumn{4}{|l|}{ Notes: } \\
\hline \multicolumn{4}{|l|}{ Extraction method: maximum likelihood. } \\
\hline \multicolumn{4}{|l|}{ Rotation method: Oblimin with Kaiser normalisation. } \\
\hline Loadings with absolute value $<0.40$ were suppressed. & & & \\
\hline
\end{tabular}


To confirm the result of the EFA, CFA was carried out. Following the approach suggested by Hair et al. (1998) and Wallace et al. (2004), the measurement model was constructed, using LISREL 8.7 (Joreskog and Sorbom, 2004), with the three latent variables (ALTRN, RSTPW and KNACQ).

The analysis used robust maximum likelihood (RML) as the main estimation method (Browne, 1987). Robust maximum likelihood adjusts the normal theory of maximum likelihood chisquare estimate for the presence of non-normality using the asymptotic covariance matrix provided (Boomsma and Hoogland, 2001). It therefore generates more accurate test statistics under conditions of non-normality (Curran et al., 1996). Robust maximum likelihood is also attractive because it works with sample sizes as small as 200 (Boomsma and Hoogland, 2001; Joreskog, 2005). Satorra and Bentler (1988) extended this method by providing a scaled chisquare test statistic $\mathrm{S}-\mathrm{B} \chi^{2}$ as an indication of goodness of fit, which behaves extremely well in nearly every condition across sample size, distribution and model specification (Curran et al., 1996; Mels, 2004). Therefore, sample covariance matrix and the corresponding asymptotic covariance matrix were used with RML.

To assess the fit of the measurement model to the data, multiple fit indices were examined including the $\chi^{2} / \mathrm{df}$ ratio, GFI (goodness-of-fit index), CFI (comparative fit index), NNFI (non-normed fit index), RMSEA (root mean square error of approximation) and SRMR (standardised root mean square residual) (Bentler and Bonnett, 1980; Kline, 1998; Bhattacherjee, 2002). As is shown in Table 6, the model fit indices demonstrate that the measurement model provides a good fit to the data.

According to Fornell and Larcher (1981), to establish convergent validity the constructs have to demonstrate the following properties: (1) all factor loadings must be significant and exceed 0.70 ; (2) construct reliabilities must exceed 0.70; (3) the AVE (average variance extracted) by each construct must exceed the variance due to measurement error for that construct (i.e. AVE must exceed 0.50). As shown in Tables 6 and 7, all of the conditions are met and the convergent validity of the instrument was deemed acceptable. Moreover, Cronbach's alpha was also calculated for each construct (Table 7) and values were all above the 0.7 recommended by Nunnally (1978). 
Table 6. Confirmatory factor analysis of original measures.

\begin{tabular}{|c|c|c|c|}
\hline \multirow[b]{2}{*}{ Items } & \multicolumn{3}{|c|}{ Constructs } \\
\hline & ALTRN & RSTPW & KNACQ \\
\hline ALTRN1 & 0.79 & & \\
\hline ALTRN2 & 0.84 & & \\
\hline ALTRN3 & 0.86 & & \\
\hline ALTRN4 & 0.91 & & \\
\hline ALTRN5 & 0.87 & & \\
\hline ALTRN6 & 0.83 & & \\
\hline RSTPW1 & & 0.77 & \\
\hline RSTPW2 & & 0.72 & \\
\hline RSTPW3 & & 0.74 & \\
\hline KNACQ1 & & & 0.74 \\
\hline KNACQ2 & & & 0.82 \\
\hline KNACQ3 & & & 0.83 \\
\hline KNACQ4 & & & 0.80 \\
\hline \multirow[t]{3}{*}{ KNACQ5 } & & & 0.76 \\
\hline & \multicolumn{2}{|c|}{ Factor correlations } & \\
\hline & ALTRN & RSTPW & KNACQ \\
\hline ALTRN & 1.00 & & \\
\hline RSTPW & -0.37 & 1.00 & \\
\hline KNACQ & -0.49 & 0.56 & 1.00 \\
\hline
\end{tabular}

Table 7. Confirmatory factor analysis of survey scale.

\begin{tabular}{|c|c|c|c|c|c|c|c|}
\hline \multirow[t]{2}{*}{ Construct } & \multirow{2}{*}{$\begin{array}{l}\text { Number of } \\
\text { items }\end{array}$} & \multirow{2}{*}{$\begin{array}{c}\text { Cronbach's } \\
\text { alpha }\end{array}$} & \multirow{2}{*}{$\begin{array}{l}\text { Construct } \\
\text { reliability }\end{array}$} & \multirow[t]{2}{*}{ AVE } & \multicolumn{3}{|c|}{ Squared factor correlations } \\
\hline & & & & & ALTRN & RSTPW & KNACQ \\
\hline ALTRN & 6 & 0.939 & 0.940 & 0.724 & 1.000 & - & - \\
\hline RSTPW & 3 & 0.787 & 0.788 & 0.553 & 0.137 & 1.000 & - \\
\hline KNACQ & 5 & 0.890 & 0.893 & 0.625 & 0.240 & 0.314 & 1.000 \\
\hline
\end{tabular}

To demonstrate discriminant validity, Fornell and Larcker (1981) recommended that AVE for each construct should exceed the squared factor correlations between that construct and other constructs. This was the case (Table 7), thus supporting the discriminant validity of the original instrument. 
Since the data were collected in a single instrument from a single respondent from each organisation, the threat of common method bias to the validity of the data was checked using Harman's (1967) one-factor test. The resulting principal component analysis returned six distinct factors with eigenvalues greater than 1 , which accounted for $70.2 \%$ of the variance and the first factor accounted for only $28.94 \%$ of the variance. The results hence led us to conclude that common method bias was not a problem.

\subsection{Hypothesis testing}

A structural equation model of the hypothetical model shown in Figure 1 was constructed to test the research hypotheses. The latent variables, ALTRN, RSTPW and KNACQ were indicated by the corresponding observed variables. Supply chain performance (SCPFRM) was indicated by the single observed variable (SCPERFRM). Again RML was used as the main estimation method with sample covariance matrix and the corresponding asymptotic covariance matrix employed. The model fit indices demonstrated acceptable model fit to the data $\left(\mathrm{S}-\mathrm{B} \chi^{2} / \mathrm{df}=2.71 ; \mathrm{GFI}=0.84 ; \mathrm{CFI}=0.96 ; \mathrm{NNFI}=0.96 ; \mathrm{RMSEA}=0.091 ; \mathrm{SRMR}=\right.$ 0.073).

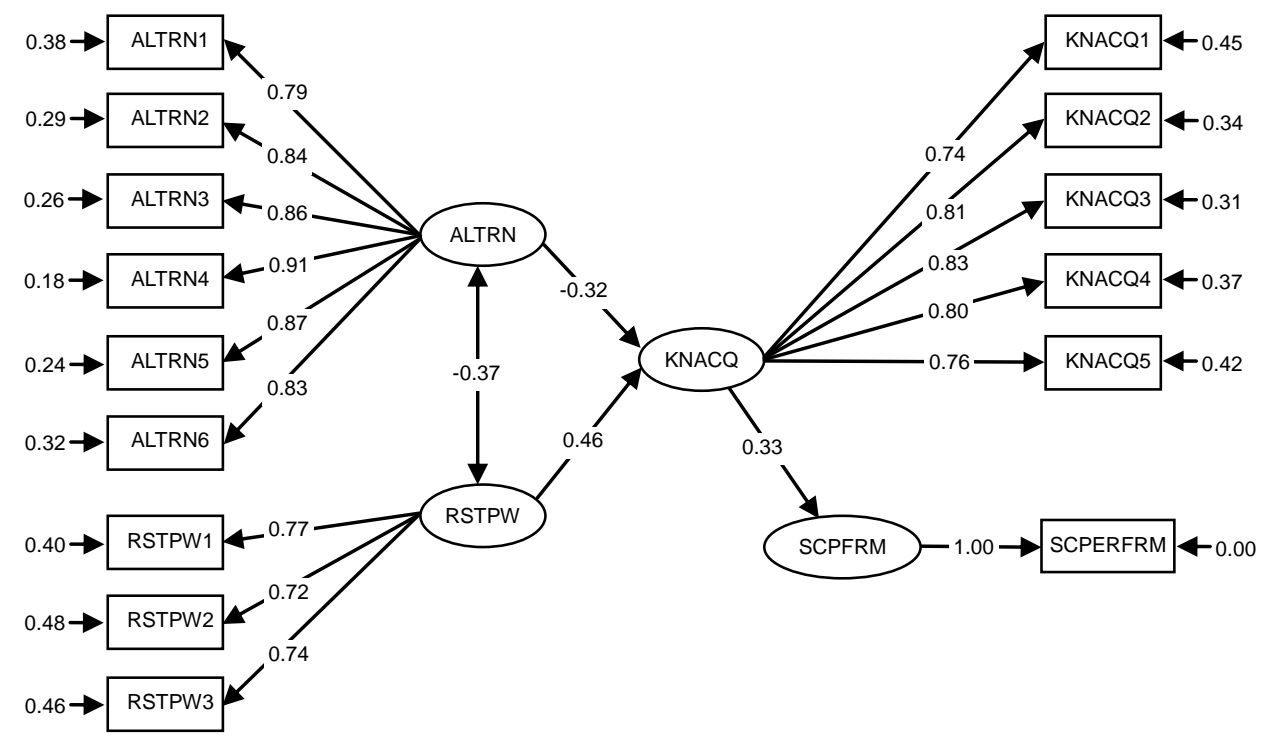

Figure 2. Path diagram of the fitted structural equation model.

Figure 2 shows the path diagram of the SEM. As shown in Table 8, the estimated path coefficient between availability of alternatives and knowledge acquisition was significant but with a negative value of -0.32 . Hypothesis 1 was therefore supported. The estimated path 
coefficient between restraint in the use of power and knowledge acquisition was significant with a positive value of 0.46 . Therefore, hypothesis 2 was also supported. The estimated correlation coefficient between availability of alternatives and restraint in the use of power was significant but with a negative value of -0.37 . Hypothesis 3 was therefore supported. The estimated path coefficient between knowledge acquisition and supply chain performance was significant with a positive value of 0.33 , thus providing support for hypothesis 4 . These results are discussed in section 6.

Table 8. Path coefficient estimates and model fit indices.

\begin{tabular}{lcccc}
\hline & \multicolumn{4}{c}{ Latent variables } \\
\cline { 2 - 4 } & ALTRN & RSTPW & KNACQ & SCPFRM \\
\hline Knowledge acquisition & $-0.32 *(-3.40)$ & $0.46^{*}(5.65)$ & - & - \\
Supply chain performance & - & - & $0.33 *(4.22)$ & - \\
Availability of alternatives & - & $-0.37 *(-3.95)$ & - & - \\
Restraint in the use of power & $-0.37 *(-3.95)$ & - & - & - \\
\hline
\end{tabular}

Notes: $\mathrm{n}=206$. $*$ Significant path estimates.

First value is the standardised parameter estimate; value in parenthesis is the t-value.

Model fit indices: Satorra-Bentler scaled $\chi^{2}=235.99, \mathrm{df}=87 ; \mathrm{S}-\mathrm{B} \chi^{2} / \mathrm{df}=2.71 ; \mathrm{GFI}=0.84 ; \mathrm{CFI}=0.96$; NNFI $=0.96$;

RMSEA $=0.091 ;$ SRMR $=0.073$.

\subsection{Testing the interaction between availability of alternatives and restraint in the use of power}

To evaluate the interaction between the two latent variables availability of alternatives and restraint in the use of power, the two-step procedure of (Ping, 1995) was followed. Thus the latent product was indicated by the product of the sums of the indicators of the two latent variables. First, loadings and errors of the latent variables were obtained from the additive measurement model (i.e. the measurement model without the latent product). Second, these values were used to calculate the loadings and error terms of the latent product, which were then used to fix the paths associated with the latent product in the interaction model (Ping, 1995). Given that the latent variables availability of alternatives and restraint in the use of power had good unidimensionality as indicated in the previous CFA analysis, it was appropriate to fix the parameter values in the structural model based on the estimates from the measurement model (Anderson and Gerbing, 1988).

As shown in Table 9, the resultant interaction model shows good model fit $\left(\chi^{2}=82.80, \mathrm{df}=\right.$ $101, \chi^{2} / \mathrm{df}=0.82, \mathrm{p}=0.91, \mathrm{CFI}=1.00$ and RMSEA $\left.<0.05\right)$. Despite the non-significant 
values, the path estimates specified in the original SEM retained the same signs in the interaction model. The interaction variable showed a negative effect on knowledge acquisition with a significant value of -0.23 . Figure 3 presents the plot of interaction based on the standardised path coefficients. It can be seen that when ALTRN is at a lower level (i.e. the supply chain partner is more difficult to replace by the responding firm), the restraint in the use of power in the partnership has a positive effect on knowledge acquisition. However, when ALTRN is at a higher level (i.e. the responding firm has more alternative partner choices), the restraint in the use of power in the partnership has a less clear effect on knowledge acquisition.

Table 9. Path coefficient estimates and model fit indices with latent product.

\begin{tabular}{lccccc}
\hline & \multicolumn{5}{c}{ Latent variables } \\
\cline { 2 - 5 } & ALTRN & RSTPW & ALTRN*RSTPW & KNACQ & SCPFRM \\
\hline Knowledge acquisition & $-0.06(-0.41)$ & $0.59(1.64)$ & $-0.23 *(-2.22)$ & - & - \\
Supply chain performance & - & - & - & $0.29(1.57)$ & - \\
Availability of alternatives & - & $-0.43(-1.33)$ & - & - & - \\
Restraint in the use of power & $-0.43(-1.33)$ & - & - & - \\
\hline
\end{tabular}

Notes: $\mathrm{n}=206 .{ }^{*}$ Significant path estimates.

First value is the standardised parameter estimate; value in parenthesis is the t-value.

Model fit indices: Satorra-Bentler scaled $\chi^{2}=82.80, \mathrm{df}=101 ; \mathrm{S}-\mathrm{B} \chi^{2} / \mathrm{df}=0.82 ; \mathrm{GFI}=0.76 ; \mathrm{CFI}=1.00 ; \mathrm{NNFI}=1.00$;

RMSEA $<0.05 ;$ SRMR $=0.17$.

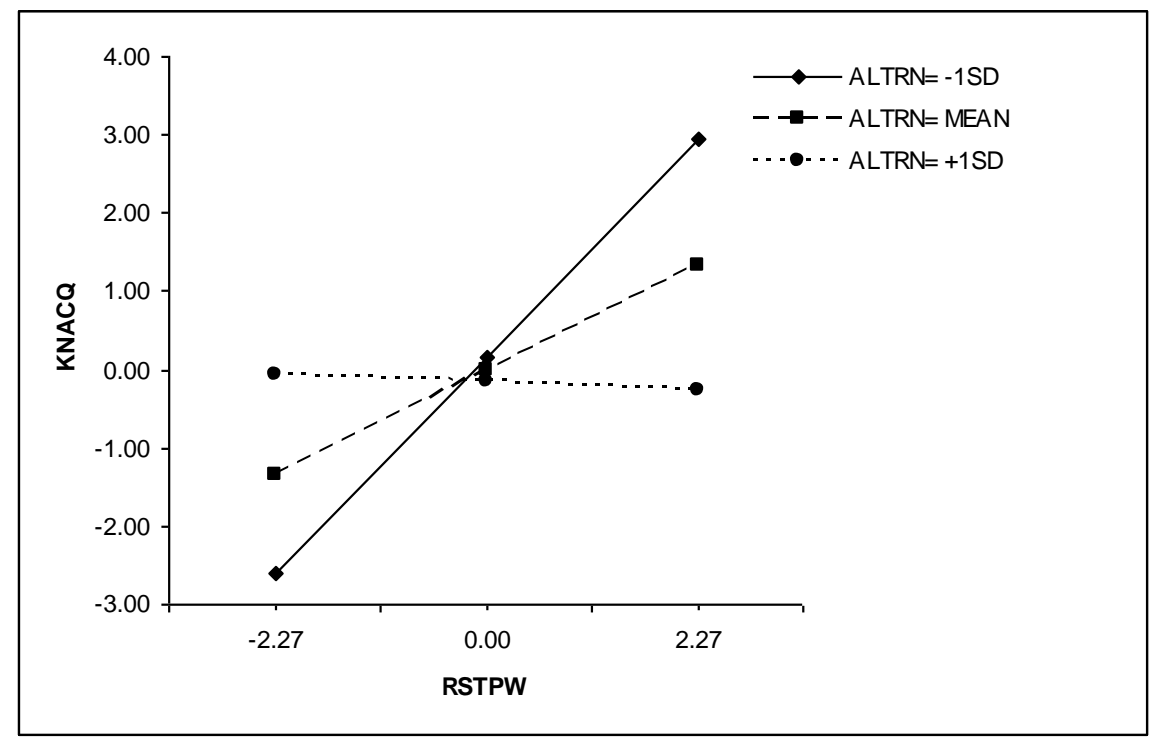

Figure 3. Plot of the interaction between availability of alternatives and restraint in the use of power. 


\subsection{Controlling for partnership duration}

Previous research suggested that the dynamics of supply chain partnerships may vary according to relationship duration (Heide and Miner, 1992; Monczka et al., 1995). We therefore examined whether partnership duration will moderate the hypothesised relationships specified in the model. To examine the moderation effect of partnership duration, a multiple group analysis was conducted. The reported partnership durations were examined first. Around half of the sample indicated less than seven years of partnership history $(n=113)$, the other half (approx.) indicating seven years or more $(n=93)$. The sample was therefore split on this basis.

Before the multigroup structural model was examined, a multigroup CFA was conducted with the two samples (Hair et al., 1998). As shown in Table 10, the configural invariance model showed good model fit $\left(\chi^{2}=93.48, \mathrm{df}=148, \mathrm{p}=1.00, \mathrm{CFI}=1.0\right.$ and RMSEA $\left.<0.005\right)$ indicating that the basic factor structure exists in both groups. When equal intercept was constrained across groups, the chi-square change was shown to be significant ( $\Delta \chi^{2}=56.13$, $\Delta \mathrm{df}=14)$, indicating that scalar invariance was not supported. However, the non-significant chi-square change ( $\left.\Delta \chi^{2}=10.76, \Delta \mathrm{df}=14\right)$ in the metric invariance model suggested that both groups exhibit equivalence in factor loadings, therefore supporting metric invariance, and indicating that the multigroup structural model comparison was appropriate to undertake (Hair et al., 1998).

Table 10. Test of invariance of measurement model across groups.

\begin{tabular}{llllllllllll}
\hline No. & \multirow{2}{*}{ Model } & $\chi^{2}$ & df & P-value & $\chi^{2} / \mathrm{df}$ & CFI & RMSEA & $\begin{array}{l}\text { Nested } \\
\text { models }\end{array}$ & $\Delta \chi^{2}$ & $\Delta$ df \\
\hline 1 & Configural invariance & 93.48 & 148 & 1.00 & 0.632 & 1.00 & $<0.005$ & - & - & - \\
2 & Metric invariance & 104.24 & 162 & 1.00 & 0.643 & 1.00 & $<0.005$ & $2-1$ & 10.76 & 14 \\
3 & Scalar invariance & 160.37 & 176 & 0.79 & 0.911 & 1.00 & $<0.05$ & $3-2$ & 56.13 & 14 \\
\hline Note: $\chi^{2}$ is the Satorra-Bentler Scaled chi-square. \\
Partnership duration short, $\mathrm{n}=113$; partnership duration long: $\mathrm{n}=93$. \\
\hline
\end{tabular}

First, the SEM specified in Figure 2 was fitted to the short-duration and long-duration samples, without any equality constraints, to produce the totally free model. Path estimates between latent constructs were then constrained to produce the constrained models (see Table 11). In model 2 the path estimate between knowledge acquisition and supply chain performance was constrained across groups first. The negative chi-square change $\left(\Delta \chi^{2}=-\right.$ 
1.33, $\Delta \mathrm{df}=1$ ) suggests that constraining the path estimate produced better model fit, and the partnership duration did not moderate the relationship between knowledge acquisition and supply chain performance.

Table 11. Test of partnership duration as a moderator.

\begin{tabular}{|c|c|c|c|c|c|c|c|c|c|c|}
\hline No. & Model & $\chi^{2}$ & df & P-value & $\chi^{2} / \mathrm{df}$ & CFI & RMSEA & $\begin{array}{l}\text { Nested } \\
\text { models }\end{array}$ & $\Delta \chi^{2}$ & $\mathrm{~d} f$ \\
\hline 1 & Unconstrained model & 129.07 & 174 & 1.00 & 0.742 & 1.00 & $<0.005$ & - & - & - \\
\hline 2 & $\begin{array}{l}\text { KNACQ } \rightarrow \text { SCPFRM } \\
\text { equal across groups }\end{array}$ & 127.74 & 175 & 1.00 & 0.730 & 1.00 & $<0.005$ & $2-1$ & -1.33 & 1 \\
\hline 3 & $\begin{array}{l}\text { ALTRN, RSTPW } \rightarrow \\
\text { KNACQ equal across } \\
\text { groups }\end{array}$ & 120.59 & 176 & 1.00 & 0.685 & 1.00 & $<0.005$ & $3-1$ & -8.48 & 2 \\
\hline 4 & $\begin{array}{l}\text { ALTRN, RSTPW } \rightarrow \\
\text { KNACQ and KNACQ } \rightarrow \\
\text { SCPFRM equal across } \\
\text { groups }\end{array}$ & 119.45 & 177 & 1.00 & 0.675 & 1.00 & $<0.005$ & $4-2$ & -8.29 & 2 \\
\hline 5 & $\begin{array}{l}\text { ALTRN, RSTPW } \rightarrow \\
\text { KNACQ and KNACQ } \rightarrow \\
\text { SCPFRM, and PH equal } \\
\text { across groups }\end{array}$ & 112.25 & 180 & 1.00 & 0.624 & 1.00 & $<0.005$ & $5-4$ & -7.20 & 3 \\
\hline
\end{tabular}

In model 3, the path estimates between availability of alternatives, restraint in the use of power, and knowledge acquisition were constrained. Again the negative chi-square change compared with the unconstrained model suggests that partnership duration does not moderate the effect of availability of alternatives and restraint in the use of power on knowledge acquisition. Model 4 constrained path estimates between availability of alternatives, restraint in the use of power, and knowledge acquisition and the path between knowledge acquisition and supply chain performance. Again, the non-significant chi-square change suggested there is no moderation effect from the partnership duration. Similarly, when covariance between exogenous variables (i.e. availability of alternatives and restraint in the use of power) were constrained, the chi-square change was not significant, and hence partnership duration did not moderate the relationship between availability of alternatives and restraint in the use of power.

Overall, the multigroup structural model evaluation suggested that partnership duration does not moderate the path estimates specified in the full model and that there is no major difference across groups of different partnership duration. This finding partly echoes the view of Gadde and Snehota (2000), that the relationship between partnership dynamics and 
partnership duration could be mixed.

\section{Discussion}

Our findings provide support for the original hypotheses. As expected, and in line with findings of previous studies (e.g. Wu and Hsu, 2001; Kotabe et al., 2003; Modi and Mabert, 2007; Lawson et al., 2009), knowledge acquisition activities had a positive impact on the performance of supply chain firms. Our study shows that supply chain partners do benefit from interfirm knowledge transfer activities. As suggested by Walter et al. (2007) valuable knowledge and best practices are often embedded in the supply network.

The differing effects of the two indicators of power on knowledge acquisition are noteworthy. As previously discussed, the literature suggests that availability of alternatives is a good proxy measure for actual power. Furthermore, it suggests that the availability of choice results in unbalanced power, which in turn can discourage cooperation. Maloni and Benton (2000) argued that power can lead to opportunism by partners and subsequently destroy many of the relational elements necessary for the development of effective partnerships. The availability of alternatives reduces dependence and can create an atmosphere of protecting proprietary resources and less willingness to share. In short, the proposition that availability of alternatives is likely to hamper cooperative relationships between supply chain partners accompanied with lower levels of knowledge exchange has many advocates (Anderson and Weitz, 1989; Provan and Skinner, 1989; Maloni and Benton, 2000). In our sample we found this to be the case. That is, availability of alternatives had a negative impact on knowledge acquisition. Our finding suggests that having alternatives reduces switching costs, making investment in long-term relationships comparatively more costly. In these circumstances commitment is likely to be lower, which may translate into greater reluctance to enter into close knowledge sharing activities. Furthermore, our finding resonates with Petersen et al.'s (2008) argument that conversely, high dependency often results in socialisation processes that involve knowledge exchange activities to mitigate dependency and generate a greater level of relational capital.

The second factor explaining power was restraint in the use of power and this had a positive impact on knowledge acquisition. This finding is in line with the argument proffered by a number of scholars, that partners' willingness to restrain relative power is essential for learning and knowledge transfer between supply chain partners (e.g. Buckley et al., 2006; Muthusamy et al., 2008). Restraint in the use of power diminishes the reluctance to share 
knowledge for fear of exploitation (Minbaeva, 2007). The willingness by the stronger partner to suppress its excessive power to foster partnership conditions creates a sense of equality (Maloni and Benton, 2000) encouraging greater willingness to exchange ideas and knowledge (Dyer and Nobeoka, 2000). Managers have greater control over realised power than they do on actual power, because actual power is dependent on factors such as size, position in the supply chain and firm age. Our findings therefore indicate that the controllable element of power, namely a policy of voluntary restraint in the use of power, has a significant influence on knowledge transfer and supply chain performance.

We found that firms with alternatives and whose supply chain partners were therefore easier to replace also reported less willingness to exercise restraint in the use of power (as indicated by the negative correlation between the two constructs, $r=-0.37$ ). This is in line with the view that when supply chain actors have alternatives, the more powerful party, being less dependent, is more likely to act in its own self-interests, and hence be less likely to restrain its use of power. Thus, for example, a focal firm with many suppliers of similar intermediate goods is more likely to exercise control (power) by dictating prices or quality levels, and vice versa a supplier with many alternative customers is also more likely to choose to dictate prices, quality and/or delivery schedule. On the other hand, this negative correlation is also in line with the view that restraint in the use of power by a supply chain actor is more likely to be observed when that actor has less alternatives available to them, for example when a focal firm purchases a high proportion of intermediate goods from a single supplier and has a very limited number of alternative suppliers.

We also found that the acquisition of external knowledge enhances the performance of partners operating within a supply chain. This substantiates the previous research of Dyer and Nobeoka (2000) that found a positive impact of knowledge acquisition on developing performance-improving capabilities, and adds further weight to the utility of investing in the development of platforms that support close, timely and effective interaction between supply chain partners.

We found no support for the view that partnership duration moderates the relationship between knowledge acquisition and performance. This indicates that immediate gains in performance can be realised by those supply chain partners willing to engage in knowledge sharing. It also indicates that the investment required before performance improvement from knowledge acquisition is realised is unlikely to be prohibitive. 
The test of interaction between availability of alternatives and restraint in the use of power suggests that when a responding firm is highly dependent on its supply chain partner, effective knowledge transfer is more reliant on restraint in the use of power by this more powerful partner. On the other hand, when the responding firm has greater relative power due to having more alternative partners available to it, exercising or not exercising restraint in the use of power has little effect on knowledge acquisition. In this case, it may be that there are other factors that could affect knowledge transfer; however, identification of such factors was not the purpose of this paper.

\section{Conclusions}

The primary contribution of this paper to the literature is to show the differential impact of the two indicators of power on knowledge acquisition. Our research thus offers evidence that power is multifaceted and that each factor influences knowledge acquisition differently. This in turn may explain the inconsistent findings of previous studies examining the role played by power within supply chains (e.g. Beecham and Cordey-Hayes, 1998; Cox, 1999; Dyer and Nobeoka, 2000; Maloni and Benton, 2000).

Actual power, in the shape of availability of alternatives, had a negative impact on knowledge acquisition. This supports the view that knowledge transfer is more likely to take place when one partner views another as irreplaceable. In other words, high interdependence is a catalyst for knowledge transfer. More importantly, it is the decision to exercise restraint in the use of power that positively influences knowledge acquisition. From a practical point of view this study suggests that factors under management control such as how much, and how to exercise, power have a significant influence on knowledge transfer and the overall performance of the supply chain. A key managerial implication of these findings is that management behaviour predicated on exploiting actual power is likely in the long term to be detrimental to improving performance. Instead, managers of supply chain actors in favourable positions of power are encouraged to see beyond the short-term gains resulting from lower relative switching costs and both encourage and lead further development of the cooperative relationship.

Our study further supports the view that knowledge transfer improves the performance of supply chain firms (e.g. Modi and Mabert, 2007; Lawson et al., 2009). This has important implications for the design and operation of supply chain partnerships, suggesting that one of the main goals ought to be knowledge exchange and ensuring that effective channels are put in place to facilitate it. Our finding provides a further reminder to managers that knowledge 
sharing improves performance and that supply chains offer the potential to affect knowledge transfer. A key implication for managers is the need to identify the specific mechanisms, in the specific context of their supply chain partnership, that best facilitate closer communication and hence knowledge acquisition. Typical mechanisms are visits to partners' premises, videoconferencing, and shared web-based communication platforms. A second key implication is for managers to think carefully about what type of knowledge is mutually most beneficial in the partnership's specific context, that is to say the content of knowledge transfer. To this end, Modi and Mabert (2007) suggest five categories of content: 'production/manufacturing related', 'problem solving assistance related', 'quality related', 'process control related' and 'other' (e.g. timing and innovation). Perhaps most importantly, there is an important nexus between this latter implication and the aforementioned implication for managers to ensuring that effective channels for knowledge exchange are developed. There is an opportunity for managers to carefully match each of Modi and Mabert's (2007) categories of 'content' of knowledge exchange to the existing communication channels and mechanisms in their partnership in order to maximise knowledge acquisition. Furthermore, such an exercise can identify where gaps exist and channel/mechanism improvement efforts can be prioritised. This finding also emphasises the importance both of knowledge being exchanged and of what the knowledge is about. Clearly both are important. With this in mind, future research is encouraged to examine learning theory (e.g. Huber, 1991; Hult, 1998) with a view to extending the knowledge acquisition aspect in supply chain partnership design to cater for knowledge geared towards exploration and knowledge geared towards exploitation.

Top and senior managers represented the majority of respondents in our study as they possessed first-hand knowledge of the supply chain practices in their firms. However, our study did not explicitly capture at which level or levels in the firms the knowledge acquisition was taking place. It would be interesting to see if the relationships we observed in our findings hold true at different knowledge exchange levels. For example, it would be interesting to ascertain in future research to what extent knowledge acquisition at top management versus plant/operations level is affected by the two indicators of power. Furthermore, to what extent it is knowledge acquisition at the top management team level that helps to drive performance improvement in supply chain firms versus knowledge acquisition at lower more operational levels of the firms. Answers to such questions, particularly if linked to the 'content' and 'channels' of knowledge acquisition, would further augment an understanding of how supply chain partnerships can best be designed to facilitate performance enhancing knowledge exchange 
Our finding that supply chain actors with many alternative partners are less willing to exercise restraint in the use of power, suggests that weaker parties that wish to suppress this tendency will have to be even more proactive in their efforts to help the stronger parties appreciate the potential gains that could be secured from restraining the exercise of their power. The finding suggests that the onus may therefore be with the weaker parties in the partnership to champion the cause for greater cooperation and collaboration, and furthermore to identify and instigate suitable mechanisms and practices that can facilitate these intentions. This is likely to have resource implications for them.

In summary, our study suggests that it is beneficial for managers in weaker firms to actively seek learning partnerships with stronger firms in the supply chain. Furthermore, it is more beneficial for managers of firms with superior power to exercise power proportionately and constructively and not to overlook the knowledge resident within weaker firms. It can pay dividends if boundary spanners give weaker firms greater opportunity to have a say regarding cooperation and supply chain operation, hence giving both sides a better chance of improving current practices that benefit them as individual firms and benefit the supply chain as a whole.

This research potentially has two key methodological limitations. First, it may suffer from common method bias, which refers to the artificial covariance between the predictor and criterion variables when the same respondent is providing the measure for both sets of variables (Podsakoff et al., 2003, p. 882). However, by following a tailored design method, carefully designing the scale and randomising the items in the questionnaire, the common method effects were kept at a minimum level. Moreover, a post-hoc analysis, Harman's onefactor test, was performed among all the items, revealing the presence of six distinct factors. These results suggested that common method bias was not a likely explanation for the reported findings (Andersson and Bateman, 1997).

Second, this research may also suffer from key informant bias. Although the key informant method is widely deemed to be acceptable (Chau and Tam, 1997), the richness of the information from only one informant from each firm surveyed is still limited (Tornatzky and Klein, 1982). However, since our data were collected from the supply network of one large focal firm, it is more likely that the respondents provided more consistent and reliable answers, generating a more holistic picture of the supply network studied and reducing the negative effect of key informant bias.

This research has two other limitations, which lead us to suggest important areas for further 
research. First, in this paper we focused on knowledge acquisition, which is a key part of knowledge transfer. However, knowledge transfer also involves internalisation and utilisation. The interaction between supply chain partners does not end at the point of knowledge acquisition. It is likely that other related knowledge transfer processes, such as knowledge internalisation and utilisation may also be affected by power (Makhija and Ganesh, 1997; Kim et al., 2004). Therefore, future studies should examine the effect of power on knowledge internalisation and utilisation. Second, although the network-based approach we employed tends to provide more in-depth understanding and guard against the presence of the confounding effects found in the study of unrelated supply chains, the fine-grained approach of this study could limit the generalisability of the research results to other industry contexts.

\section{Acknowledgement}

We thank the anonymous reviewers for their extensive and detailed comments on the work presented and their recommendations for improving the paper. We are very grateful for their insightful comments and advice that enabled us to incorporate important augmentations.

\section{References}

Albino, V., Garavelli, A. C., Schiuma, G., 1999. Knowledge transfer and inter-firm relationships in industrial districts: The role of the leader firm. Technovation, 19(1), 53-63.

Anderson, E., Weitz, B., 1989. Determinants of continuity in conventional industrial channel dyads. Marketing Science, 8(4), 310-323.

Anderson, E., Weitz, B., 1992. The use of pledges to build and sustain commitment in distribution channels. Journal of Marketing Research, 29(1), 18-34.

Anderson, J. C., Gerbing, D. W., 1988. Structural equation modeling in practice: A review and recommended two-step approach. Psychological Bulletin, 103, 411-423.

Anderson, J. C., Narus, J. A., 1990. A model of distributor firm and manufacturer firm working partnerships. Journal of Marketing, 54(1), 42-58.

Andersson, L. M., Bateman, T. S., 1997. Cynicism in the workplace: Some causes and effects. Journal of Organizational Behavior, 18, 449-469.

Barney, J., 1991. Firm resources and sustained competitive advantage. Journal of Management, 17(1), 99-120.

Bates, H., Slack, N., 1998. What happens when the supply chain manages you? A knowledge-based response. European Journal of Purchasing \& Supply Management, 4(1), 63-72.

Beecham, M. A., Cordey-Hayes, M., 1998. Partnering and knowledge transfer in the UK motor industry. Technovation, 18(3), 191-205.

Bentler, P. M., Bonnett, D. G., 1980. Significance tests and goodness of fit in the analysis of covariance structures. Psychological Bulletin, 88(3), 588-606.

Benton, W. C., Maloni, M., 2005. The influence of power driven buyer/seller relationships on supply chain satisfaction. Journal of Operations Management, 23(1), 1-22. 
Berthon, P., Pitt, L. F., Ewing, M. T., Bakkeland, G., 2003. Norms and power in marketing relationships: Alternative theories and empirical evidence. Journal of Business Research, 56(9), 699-709.

Bhattacherjee, A., 2002. Individual trust in online firms: Scale development and initial test. Journal of Management Information Systems, 19(1), 211-241.

Boomsma, A., Hoogland, J. J., 2001. The robustness of LISREL modeling revisited. In S. D. T. R. Cudeck \& D. Sorbom (Eds.), Structural equation models: Present and future. A festschrift in honor of Karl Joreskog (pp. 139-168). Chicago: Scientific Software International.

Browne, M. W., 1987. Robustness of statistical inference in factor analysis and related models. Biometrika, 74(2), 375-384.

Buckley, P. J., Clegg, J., Tan, H., 2006. Cultural awareness in knowledge transfer to china - the role of guanxi and mianzi. Journal of World Business, 41(3), 275-288.

Caniels, M. C. J., Gelderman, C. J., 2007. Power and interdependence in buyer supplier relationships: A purchasing portfolio approach. Industrial Marketing Management, 36(2), 219-229.

Cao, M., Zhang, Q., 2010. Supply chain collaborative advantage: A firm's perspective. International Journal of Production Economics, 128(1), 358-367.

Chau, P. Y. K., Tam, K. Y., 1997. Factors affecting the adoption of open systems: An exploratory study. MIS Quarterly, 21(1), 1-21.

Cho, D.-S., Chu, W., 1994. Determinants of bargaining power in OEM negotiations. Industrial Marketing Management, 23, 343-355.

Christopher, M., 1998. Logistics and supply chain management: Strategies for reducing cost and improving service (2nd ed.). London: FT Prentice Hall.

Cousins, P. D., 2002. A conceptual model for managing long-term inter-organisational relationships. European Journal of Purchasing \& Supply Management, 8(2), 71-82.

Cousins, P. D., Lawson, B., Squire, B., 2008. Performance measurement in strategic buyer-supplier relationships: The mediating role of socialization mechanisms. International Journal of Operations \& Production Management, 28(3), 238-258.

Cox, A., 1999. Power, value and supply chain management. Supply Chain Management: An International Journal, 4(4), 167-175.

Cox, A., 2004. Business relationship alignment: On the commensurability of value capture and mutuality in buyer and supplier exchange. Supply Chain Management: An International Journal, 9(5), 410-420.

Cox, A., Sanderson, I., Watson, G., 2001. Supply chains and power regimes: Toward an analytic framework for managing extended networks of buyer and supplier relationships. Journal of Supply Chain Management, 37(2), 28-35.

Crook, T. R., Combs, J. G., 2007. Sources and consequences of bargaining power in supply chains. Journal of Operations Management, 25(2), 546-555.

Curran, P. J., West, S. G., Finch, J. F., 1996. The robustness of test statistics to nonnormality and specification error in confirmatory factor analysis. Psychological Methods, 1(1), 16-29.

Dillman, D. A., 2000. Mail and internet surveys: The tailored design method (2nd ed.). New York: John Wiley \& Sons, Inc.

Dyer, J., Singh, H., 1998. The relational view: Cooperative strategy and sources of interorganizational competitive advantage. Academy of Management Review, 23(4), 660-679.

Dyer, J. H., Hatch, N. W., 2006. Relation-specific capabilities and barriers to knowledge transfers: Creating advantage through network relationships. Strategic Management Journal, 27(8), 701-719.

Dyer, J. H., Nobeoka, K., 2000. Creating and managing a high-performance knowledge-sharing network: The Toyota case. Strategic Management Journal, 21(3), 345-367. 
Emerson, R. M., 1962. Power-dependence relations. American Sociological Review, 27, 31-40.

Esmaeili, M., Zeephongsekul, P., 2010. Seller-buyer models of supply chain management with an asymmetric information structure. International Journal of Production Economics, 123(1), 146-154.

Ethiraj, S. K., Kale, P., Krishnan, M. S., Singh, J. V., 2005. Where do capabilities come from and how do they matter? A study in the software services industry. Strategic Management Journal, 26(1), 25-45.

Faria, A., Wensley, R., 2002. In search of 'interfirm management' in supply chains: Recognizing contradictions of language and power by listening. Journal of Business Research, 55(7), 603-610.

Fitzroy, P., Hulbert, J., Ghobadian, A., 2011. Strategic management: The challenge of creating value (2nd ed.). London: Routledge.

Fornell, C., Larcker, D. F., 1981. Evaluating structural equation models with unobservable variables and measurement error. Journal of Marketing Research, 18(1), 39-50.

Frankel, R., Whipple, J. S., Frayer, D. J., 1996. Formal versus informal contracts: Achieving alliance success. International Journal of Physical Distribution \& Logistics Management, 26(3), 47-63.

Gadde, L. E., Snehota, I., 2000. Making the most of supplier relationships. Industrial Marketing Management, 29, 305-316.

Ganesan, S., 1994. Determinants of long-term orientation in buyer-seller relationships. Journal of Marketing, 58, $1-19$.

Grant, R. M., 1996. Toward a knowledge-based theory of the firm. Strategic Management Journal, 17(Winter special issue), 109-122.

Gunasekaran, A., Patel, C., Tirtiroglu, E., 2001. Performance measures and metrics in a supply chain environment. International Journal of Operations \& Production Management, 21(1/2), 71-87.

Hair, J. F., Anderson, R. E., Tatham, R. L., Black, W. C., 1998. Multivariate data analysis (5th ed.). London: Prentice-Hall.

Hallikas, J., Puumalainen, K., Vesterinen, T., Virolainen, V.-M., 2005. Risk-based classification of supplier relationships. Journal of Purchasing and Supply Management, 11(2-3), 72-82.

Handfield, R. B., Lawson, B., 2007. Integrating suppliers into new product development. Research-Technology Management, 50(5), 44-51.

Handfield, R. B., Ragatz, G. L., Petersen, K. J., Monczka, R. M., 1999. Involving suppliers in new product development. California Management Review, 42(1), 59-82.

Hardwick, R., Ford, D., 1986. Industrial buyer resources and responsibilities and the buyer seller relationship. Industrial Marketing and Purchasing, 1(3), 35-48.

Harman, H. H., 1967. Modern factor analysis (2nd ed.). Chicago: The University of Chicago Press.

Harrigan, K. R., Newman, W. H., 1990. Bases of interorganization co-operation: Propensity, power, persistence. Journal of Management Studies, 27, 417-434.

Heide, J. B., John, G., 1988. The role of dependence balancing in safeguarding transaction-specific assets in conventional channels. Journal of Marketing, 52(1), 20.

Heide, J. B., Miner, A. S., 1992. The shadow of the future: Effects of anticipated interaction and frequency of contact on buyer-seller cooperation. Academy of Management Journal, 35(2), 265-291.

Hillman, A. J., Withers, M. C., Collins, B. J., 2009. Resource dependence theory: A review. Journal of Management, 35(6), 1404-1427.

Hingley, M. K., 2005. Power to all our friends? Living with imbalance in supplier-retailer relationships. Industrial Marketing Management, 34(8), 848-858.

Huber, G. P., 1991. Organizational learning: The contributing processes and the literatures. Organization Science, 2(1), 88-115.

Hult, G. T. M., 1998. Managing the international strategic sourcing function as a market-driven organizational 
learning system. Decision Sciences, 29(1), 193-216.

Hult, G. T. M., Ketchen, D. J., Nichols, E. L., 2002. An examination of cultural competitiveness and order fulfillment cycle time within supply chains. Academy of Management Journal, 45(3), 577-586.

Hult, G. T. M., Ketchen, D. J., Slater, S. F., 2004. Information processing, knowledge development, and strategic supply chain performance. Academy of Management Journal, 47(2), 241-253.

Inkpen, A., 1998. Learning, knowledge acquisition, and strategic alliances. European Management Journal, 16(2), 223-229.

Inkpen, A. C., Dinur, A., 1998. Knowledge management processes and international joint venture. Organization Science, 9(4), 454-468.

Ireland, P., 1999. Satisfying dependent customers: On the power of suppliers in IT systems integration supply chains. Supply Chain Management: An International Journal, 4(4), 184-191.

Joreskog, K. G., 2005. Structural equation modeling with ordinal variables using LISREL. Lincolnwood, IL: Scientific Software International, Inc.

Joreskog, K. G., Sorbom, D., 2004. LISREL 8.70. Lincolnwood, IL, USA: Scientific Software International, Inc.

Joshi, A. W., Sharma, S., 2004. Customer knowledge development: Antecedents and impact on new product performance. Journal of Marketing, 68(4), 47-59.

Ke, W., Liu, H., Wei, K. K., Gu, J., Chen, H., 2009. How do mediated and non-mediated power affect electronic supply chain management system adoption? The mediating effects of trust and institutional pressures. Decision Support Systems, 46, 839-851.

Ke, W., Wei, K. K., 2007. Factors affecting trading partners' knowledge sharing: Using the lens of transaction cost economics and socio-political theories. Electronic Commerce Research and Applications, 6(3), 297-308.

Kemp, R. G. M., Ghauri, P. N., 2001. Interdependency in joint ventures : The relationship between dependence asymmetry and performance. Chain and network science, 101-110.

Kim, A., Lim, E.-Y., 1999, April 19-23, 1999. How critical is back translation in cross-cultural adaptation of attitude measures? Paper presented at the Annual Meeting of the American Educational Research Association, Montreal, Quebec, Canada.

Kim, H., Hoskisson, R. E., Wan, W. P., 2004. Power dependence, diversification strategy, and performance in keiretsu member firms. Strategic Management Journal, 25(7), 613-636.

Kline, R., 1998. Principles and practices of structural equation modeling. New York: The Guilford Press.

Kogut, B., Zander, U., 1992. Knowledge of the firm, combinative capabilities, and the replication of technology. Organization Science, 3(3), 383-397.

Kotabe, M., Martin, X., Domoto, H., 2003. Gaining from vertical partnerships: Knowledge transfer, relationship duration, and supplier performance improvement in the US and Japanese automotive industries. Strategic Management Journal, 24(4), 293-316.

Krajewski, L., Wei, J. C., Tang, L.-L., 2005. Responding to schedule changes in build-to-order supply chains. Journal of Operations Management, 23(5), 452-469.

Krause, D. R., Handfield, R. B., Tyler, B. B., 2007. The relationships between supplier development, commitment, social capital accumulation and performance improvement. Journal of Operations Management, 25(2), 528-545.

Kumar, N., Scheer, L. K., Steenkamp, J. E. M., 1995. The effects of perceived interdependence on dealer attitudes. Journal of Marketing Research, 32, 348-358.

Lambert, D. M., Emmelhainz, M. A., Gardner, J. T., 1996. Developing and implementing supply chain partnerships. The International Journal of Logistics Management, 7(2), 1-17.

Lascelles, D. M., Dale, B. G., 1989. The buyer-supplier relationship in total quality management. Journal of 
Purchasing and Materials Management, 25(2), 10-19.

Lawson, B., Petersen, K., Cousins, P. D., Handfield, R. B., 2009. Knowledge sharing in interorganizational product development teams: The effect of formal and informal socialization mechanisms. Journal of Product Innovation Management, 26(2), 156-172.

Levinson, N. S., Asahi, M., 1995. Cross-national alliances and interorganizational learning. Organizational Dynamics, 24, 51-63.

Li, S. X., Huang, Z., Zhu, J., Chau, P. Y. K., 2002. Cooperative advertising, game theory and manufacturerretailer supply chains. Omega, 30(5), 347-357.

Liu, H., Ke, W., Wei, K. K., Gu, J., Chen, H., 2010. The role of institutional pressures and organizational culture in the firm's intention to adopt internet-enabled supply chain management systems. Journal of Operations Management, 28(5), 372-384.

Love, P. E. D., Gunasekaran, A., 1999. Learning alliances: A customer-supplier focus for continuous improvement in manufacturing. Industrial and Commercial Training, 31(3), 88-96.

Makhija, M. V., Ganesh, U., 1997. The relationship between control and partner learning in learning-related joint ventures. Organization Science, 8(5), 508-527.

Maloni, M., Benton, W. C., 2000. Power influences in the supply chain. Journal of Business Logistics, 21(1), 4973.

Maxwell, B., 1996. Translation and cultural adaptation of the survey instruments. In M. O. Martin \& D. L. Kelly (Eds.), Third international mathematics and science study (TIMSS) technical report, volume i: Design and development. Chestnut Hill, MA: Boston College.

Mcdonald, F., 1999. The importance of power in partnership relationships. Journal of General Management, 25(1), 43-59.

Mels, G., 2004. LISREL 8.7 for windows: Getting started guide. Lincolnwood, IL: Scientific Software International, Inc.

Minbaeva, D. B., 2007. Knowledge transfer in multinational corporations. Management International Review, 47(4), 567-593.

Modi, S. B., Mabert, V. A., 2007. Supplier development: Improving supplier performance through knowledge transfer. Journal of Operations Management, 25, 42-64.

Monczka, R. M., Callahan, T. J., Nichols, E. L., 1995. Predictors of relationships among buying and supplying firms. International Journal of Physical Distribution \& Logistics Management, 25(10), 45-59.

Mowery, D. C., Oxley, J. E., Silverman, B. S., 1996. Strategic alliances and interfirm knowledge transfer. Strategic Management Journal, 17(Winter special issue), 77-91.

Murray, J. Y., Kotabe, M., Wildt, A. R., 1995. Strategic and financial performance implications of global sourcing strategy: A contingency analysis. Journal of International Business Studies, 26(1), 181-202.

Murray, J. Y., Kotabe, M., Zhou, J. N., 2005. Strategic alliance-based sourcing and market performance: Evidence from foreign firms operating in china. Journal of International Business Studies, 36, 187-208.

Muthusamy, S. K., Hur, D., Palanisamy, R., 2008. Leveraging knowledge in buyer-supplier alliances: A theoretical integration. International Journal of Management and Decision Making, 9(6), 600-616.

Muthusamy, S. K., White, M. A., 2005. Learning and knowledge transfer in strategic alliances: A social exchange view. Organization Studies, 26(3), 415-441.

Muthusamy, S. K., White, M. A., 2006. Does power sharing matter? The role of power and influence in alliance performance. Journal of Business Research, 59(7), 811-819.

Narasimhan, R., Nair, A., Griffith, D. A., Arlbjorn, J. S., Bendoly, E., 2009. Lock-in situations in supply chains: A social exchange theoretic study of sourcing arrangements in buyer-supplier relationships. Journal of Operations Management, 27(5), 374-389. 
New, S., 1998. The implications and reality of partnership. In B. Burnes \& B. Dale (Eds.), Working in partnership: Best practice in customer-supplier relations (pp. 9-20). Hampshire, UK: Gower Publishing Ltd.

Nunnally, J. C., 1978. Psychometric theory (2nd ed.). New York: McGraw-Hill.

Ogbonna, E., Wilkinson, B., 1998. Power relations in the UK grocery supply chain : Developments in the 1990s. Journal of Retailing and Consumer Services, 5(2), 77-86.

Panayides, P. M., Venus Lun, Y. H., 2009. The impact of trust on innovativeness and supply chain performance. International Journal of Production Economics, 122(1), 35-46.

Pedroso, M. C., Nakano, D., 2009. Knowledge and information flows in supply chains: A study on pharmaceutical companies. International Journal of Production Economics, 122(1), 376-384.

Pekar, P., Allio, R., 1994. Making alliances work: Guidelines for success. Long Range Planning, 27(4), 54-65.

Petersen, K., Handfield, R. B., Lawson, B., Cousins, P. D., 2008. Buyer dependency and relational capital formation: The mediating effects of socialization processes and supplier integration. Journal of Supply Chain Management, 44(4), 53-65.

Pfeffer, J., Salancik, G. R., 1978. The external control or organizations - a resource dependence perspective. New York: Harper and Row Publishers.

Pfeffer, J., Salancik, G. R., 2003. The external control of organizations: A resource dependence perspective. Stanford, CA: Stanford University Press.

Phillips, L. W., 1981. Assessing measurement error in key informant reports: A methodological note on organizational analysis in marketing. Journal of Marketing Research, 16, 395-415.

Ping, R. A., 1995. A parsimonious estimating technique for interaction and quadratic latent variables. Journal of Marketing Research, 32, 336-347.

Podsakoff, P. M., Dalton, D. R., 1987. Research methodology in organizational studies. Journal of Management, 13(2), 419-441.

Podsakoff, P. M., Mackenzie, S. B., Lee, J.-Y., Podsakoff, N. P., 2003. Common method biases in behavioral research: A critical review of the literature and recommended remedies. Journal of Applied Psychology, 88(5), 879-903.

Provan, K. G., Gassenheimer, J. B., 1994. Supplier commitment in relational contract exchanges with buyers: A study of interorganizational dependence and exercised power. Journal of Management Studies, 31(1), 55-68.

Provan, K. G., Skinner, S. J., 1989. Interorganizational dependence and control as predictors of opportunism in dealer-supplier relations. Academy of Management Journal, 32(1), 202.

Ramasamy, B., Goh, K. W., Yeung, M. C. H., 2006. Is guanxi (relationship) a bridge to knowledge transfer? Journal of Business Research, 59(1), 130-139.

Ramsay, J., 1996. Power measurement. European Journal of Purchasing \& Supply Management, 2(2-3), 129-143.

Rauniar, R., Doll, W., Rawski, G., Hong, P., 2008. Shared knowledge and product design glitches in integrated product development. International Journal of Production Economics, 114(2), 723-736.

Robson, C., 1993. Real world research: A resource for social scientists and practitioner-researchers. Oxford, UK: Blackwell.

Robson, C., 2002. Real world research (2nd ed.). London: Blackwell.

Sanderson, J., 2001. The impact of regulation on buyer and supplier power. Journal of Supply Chain Management, 37(2), 16-21.

Satorra, A., Bentler, P. M., 1988. Scaling corrections for chi-square statistics in covariance structure analysis. Alexandria, VA: American Statistical Association.

Spekman, R. E., Spear, J., Kamauff, J., 2002. Supply chain competency: Learning as a key component. Supply 
Chain Management: An International Journal, 7(1), 41-55.

Storer, C. E., Soutar, G. N., Quaddus, M., 2005. Comparative pairs analysis for IOIS research. In S. B. Eom (Ed.), Inter-organizational information systems in the internet age (pp. 297-327). Hershey PA: Idea Group Publishing.

Sucky, E., 2006. A bargaining model with asymmetric information for a single supplier-single buyer problem. European Journal of Operational Research, 171(2), 516-535.

Tornatzky, L. G., Klein, K. J., 1982. Innovation characteristics and innovation adoption-implementation: A metaanalysis of findings. IEEE Transactions on Engineering Management, 29(1), 28-45.

Ulrich, D., Barney, J. B., 1984. Perspectives in organizations: Resource dependence, efficiency, and population. Academy of Management Review, 9, 471-481.

Waheed, K. A., Gaur, S. S., 2012. An empirical investigation of customer dependence in interpersonal buyerseller relationships. Asia Pacific Journal of Marketing and Logistics, 24(1), 102-124.

Wallace, L., Keil, M., Rai, A., 2004. How software project risk affects project performance: An investigation of the dimensions of risk and an exploratory model. Decision Sciences, 35(2), 289-321.

Walter, J., Lechner, C., Kellermanns, F. W., 2007. Knowledge transfer between and within alliance partners: Private versus collective benefits of social capital. Journal of Business Research, 60(7), 698-710.

Watson, G., 1999. Power and value appropriation in the direct-marketing publishing supply chain. Supply Chain Management: An International Journal, 4(4), 192-198.

Watson, G., 2001. Subregimes of power and integrated supply chain management. Journal of Supply Chain Management, 37(2), 36-41.

Williamson, O. E., 1975. Market and hierarchies. Englewood Cliffs, NJ: Prentice-Hall.

Wilson, D. T., 1995. An integrated model of buyer-seller relationships. Journal of the Academy of Marketing Science, 23(4), 335-345.

Wu, F., Cavusgil, S. T., 2006. Organizational learning, commitment, and joint value creation in interfirm relationships. Journal of Business Research, 59(1), 81-89.

Wu, S.-H., Hsu, F. B., 2001. Towards a knowledge-based view of OEM relationship building: Sharing of industrial experiences in Taiwan. International Journal of Technology Management, 22(5-6), 503-523.

Yan, A., Gray, B., 1994. Bargaining power, management control and performance in united states-china joint ventures: A comparative case study. Academy of Management Journal, 37(6), 1478-1517.

Yeung, A. H. W., Lo, V. H. Y., Yeung, A. C. L., Cheng, T. C. E., 2008. Specific customer knowledge and operational performance in apparel manufacturing. International Journal of Production Economics, 114(2), 520-533.

Yeung, J. H. Y., Selen, W., Zhang, M., Huo, B., 2009. The effects of trust and coercive power on supplier integration. International Journal of Production Economics, 120(1), 66-78.

Zhao, X., Huo, B., Flynn, B. B., Yeung, J. H. Y., 2008. The impact of power and relationship commitment on the integration between manufacturers and customers in a supply chain. Journal of Operations Management, 26(3), 368-388. 